\title{
Även om jag förlåter så är det ändå inte förlåtet
}

\author{
Föredrag vid Svenska litteratursällskapet i Finlands årshögtid \\ den 5 februari 2019
}

EN BILD PÅ MIN PAPPA I UNGDOMEN där han ligger och sover i solen under ett träd, en solstråle har hittat honom där han slumrar i en brun manchesterkavaj och lite för stora skor. Låt honom sova en liten stund till, låt den första solen värma hans ansikte, som en humla i frostigt gräs som man försöker väcka genom att blåsa på den. Snart börjar livet. Det kommer att bli ett svårt liv. Redan från början är så mycket för sent. Och när jag ser honom nu, i skrivandets ögonblick, ser jag att han bara följer en rörelse som har börjat långt före honom, som ligger nedärvd i generationer. Det jag skriver har fått mig att tänka på förlåtelsen.

Den franske filosofen Jacques Derrida menar att vi ofta förväxlar förlåtelsen med andra saker. Med ursäkten, med politiken, med normalitet, med ekonomi. För det är bara det oförlåtliga som går att förlåta, som han skriver i "Le Siècle et le Pardon" (200I). ${ }^{1}$ Det låter som en återvändsgränd, men är i själva verket en öppning. Och det är logiskt. För om vi bara är beredda att förlåta "det som går att förlåta”, ja, då förlorar ju förlåtelsen sin mening. Förlåtelsen kan alltid bara

I. Jacques Derrida, "Le Siècle et le Pardon", Foi et Savoir, Paris: Seuil 2oor; se även Louise du Toit, "Våldtäktsfrågan", översättning till svenska: Göran Dahlberg \& Elin Talje, Glänta 4.o6 Sanning och försoning, Göteborg: Glänta, s. 68-82. Tillgänglig elektroniskt: http://glanta.org/tidskrift/alla-nummer/?viewArt=IoI2 (hämtad 28/8 2019). 
röra det oförlåtliga, det vill säga det oerhörda, det som tar sönder en människa så att hon aldrig går att laga igen. Därför är förlåtelse alltid det omöjliga, en paradox, ett vansinne och en dröm.

I romanen Ränderna gestaltar den svenska författaren Magnus Florin Derridas tanke. I ett imaginärt möte med sin döda mor, som när han var barn simmade in i självmordsdöden och lämnade honom ensam i världen. $\mathrm{Nu}$ möts de i en leksaksbutik:

Borde jag ångra mig? Jag ångrar mig inte. Du fick det väl bra ändå? Kanske bättre än om jag hade levt. [...] Det känns som om jag nu borde fråga dig ifall du kan förlåta mig?

- Vill du fråga det?

Nej. Verkar jag förhärdad? Det är inte meningen. Men det känns meningslöst med sådana frågor. "Kan du förlåta mig?” Det är väl sådant man säger om man trampar någon på tårna på bussen? Det jag gjorde är oförlåtligt. Hur skulle man kunna förlåta något sådant? De som blir kvar måste väl leva med det ändå? Det oförlåtliga är oförlåtligt hela tiden, men det går väl att uthärda? Och i längden är väl det oförlåtliga det enda som är värt att förlåta? ${ }^{2}$

Och eftersom det bara är det oförlåtliga som går att förlåta så kan aldrig frågan om förlåtelse gå över, den måste alltid hållas öppen, den förblir oavslutad, för evigt en öppen fråga och ett öppet sår. Det vill säga, det går aldrig att bestämma sig en gång för alla för icke-förlåtelse eftersom det oförlåtliga fortfarande är just det som är det enda som är möjligt att förlåta.

Frågan om det oförlåtliga och om förlåtelsen är en pil som flyger för evigt.

"Och även om jag förlåter så är det ändå inte förlåtet", som hon säger, Marie, den intagna dottern i Lars Noréns pjäs Ett sorts Hades. ${ }^{3}$

2. Magnus Florin, Ränderna, Stockholm: Albert Bonniers förlag 2010, s. 92.

3. Ett sorts Hades, svensk tv-film i regi av Lars Norén och Torbjörn Ehrnvall. Visades i två delar av Sveriges Television, 30/II I996 (del I) och I/I2 I996 (del 2). 
Jag tänker på det oförlåtliga i termer av mått, storlek och proportion. Det oförlåtliga är det oerhörda, det måttlösa, det som är så stort att det inte får plats i världen och $\mathrm{i}$ tanken, det som repar upp ett avgrundssår i världen, det som får allt att rämna. Och kanske är det en del av problemet att det oförlåtliga ligger utanför tanken, det saknar mått och mänskliga proportioner. Det är handlingarna vi inte kan föreställa oss, de som är så ogripbara att de blir svåra att minnas. Vi känner alla någon som har blivit utsatt för något oerhört, men ingen känner förövarna. Var finns de? Står de någonstans utanför tankens räckvidd och ser på oss?

I Kvinnan som matade hundarna av den belgiska författaren Kristien Hemmerechts har huvudpersonen gjort det oförlåtliga, hon är medbrottsling till en pedofil och en mördare, hon har låtit hans brott ske i deras gemensamma hus, hon har sett allt utan att ingripa. $\mathrm{Nu}$ är hon i fängelse, utan sina barn:

Jag har fått henne att lova att aldrig berätta för någon vem hennes föräldrar är."Avslöja inte det, Elise. Även om du tror att du kan lita på en person. Du kan inte lita på någon. Det är mitt fel och din fars fel. Jag vet det. Jag skulle ge allt för att göra det ogjort, men det kan jag inte." [...]

"Jag lovar att jag aldrig ska avslöja för någon vem jag är."

"Inte heller för pengar", sa jag.

"Inte heller för pengar", upprepade hon.

"Eller för en iPad."

"Eller för en iPad."

Jag knäböjde bredvid min dotter och bad. Ständigt samma bön:

Låt ingen hämnas på mina barn.

Öga för öga, tand för tand, barn för barn. ${ }^{4}$

Den dömda i den här romanen hoppas inte på förlåtelse för egen del, men för sina barn.

4. Kristien Hemmerechts, Kvinnan som matade hundarna, översättning till svenska: Olov Hyllienmark, Malmö: Rámus 2015, s. I48-I49. 
Man skulle kunna tänka sig att det inom oss finns någonting som alltid är berett att förlåta och någonting som är lika starkt, som är helt oresonligt, utan nåd. Ytterst har du att välja mellan att förlåta en människa eller att döda henne. Staten har ju våldsmonopolet så det är inte en reell möjlighet, men man kan ju alltid stå kvar där med sitt imaginära vapen och sitt ressentiment och vägra vapenvila och försoning. Juridiken är ändå någonting annat än förlåtelsen. Lagen är kall som ett svärd, den bryr sig inte om att det bara är den fattiga som behöver stjäla bröd och sova under broarna, den bryr sig inte om huruvida den våldtagna har druckit kaffe eller farit till Paris eller världens ände med förövaren efteråt. Juridiken är bara intresserad av den brottsliga handlingen, i det är den naturvetenskaplig och inte moralisk, den intresserar sig bara för handen som griper efter det den inte äger, för handen som håller fast ett huvud och inte släpper taget. Lagen är inte hjärtat, inte moralen, inte hela världen. Och du behöver inte förlåta någon för att den har tagit, eller suttit av, sitt straff, även om du motsatsvis kan förlåta någon trots att denna inte tagit sitt straff. Men det enda du kan förlåta är det oförlåtliga.

Inte heller spelar det någon roll om den skyldige har erkänt eller bett om förlåtelse, säger Derrida. För om erkännandet skulle vara en förutsättning för förlåtelse skulle vi vara utlämnade till brottslingen ännu en gång. Och Derrida går ännu längre och menar att förlåtelsen inte heller kan grunda sig på att den skyldige har ändrat sig och blivit en bättre människa som aldrig tänker göra ont igen, för då är det ju i praktiken en annan än förbrytaren och dennes förbrytelse vi förlåter. Verklig förlåtelse är ovillkorlig och den har ingenting med förnuft eller rationalitet att göra. Den är oerhörd, blind, bortom.

Den amerikanska poeten Claudia Rankine skriver om förlåtelsen:

För den som förlåter, är den bara en död, en nedsläckning i hjärtat, den redan dödas position [...]. Den är en känsla av intighet som inte kan kommuniceras till någon annan, en frånvaro, ett bottenlöst tomrum som upprätthålls av de levande, bortom allt det som är hatat eller älskat. ${ }^{5}$

5. "For the one who forgives, it is simply a death, a dying down in the heart, the position of the already dead [...]. It is a feeling of nothingness that cannot be communicated to another, an absence, a bottomless vacancy held by the living, beyond all that is hated and loved", Claudia Rankine, Don't Let Me Be Lonely: An American Lyric, 
Jesus och Hannah Arendt säger att grunden för förlåtelsen är att människorna inte vet vad de gör. Utan förlåtelse ingen framtid, sade Desmond Tutu. Verklig försoning är fruktansvärd, ur det kristna korsets perspektiv kostade den Gud hans ende son. I Sydafrika byggde man ett nytt samhälle utifrån förlåtelsen efter apartheid. Men ett stort problem med försoning och förlåtelse är att offren ofta redan är döda, att de som är de enda som skulle kunna förlåta inte kan välja själva. Kan vi förlåta för andras räkning, för de döda, eller bör vi hålla fast vid de dödas eventuella oförsonlighet, just för att de döda saknar röst?

Förlåtelse kräver en sorts suveränitet hos den som ska förlåta, men själva utsattheten berövar den utsatta, inte bara livet ibland, utan också möjligheten att tala, den utplånar friheten och kraften och makten som ger auktoritet att säga: "Jag förlåter." Och det är så Derrida till slut når fram till en sorts definition av vad det oförlåtliga är. Det oförlåtliga är att beröva en människa just denna suveränitet, det vill säga hennes möjlighet att tala, att hon på grund av det söndertrasade inom henne inte ens kan ta möjligheten i akt att förlåta det oförlåtliga. Våldtäkt är en handling som utplånar den där kraften och friheten och makten att säga: "Jag anklagar." Eller "jag förlåter". Våldtäkten tycks för övrigt tillhöra både det oförlåtliga och det väldigt vardagliga.

Men Derrida drömmer om en förlåtelse utan en sådan suveränitet. En Philomela med utskuren tunga som talar ändå. En omöjlighet, en utopi, en galenskap, ett vilt hopp om en annan värld. Och litteraturen är den enda plats där de döda kan tala utan tungor och med jord i munnen. I min senaste roman Kärlekens Antarktis är huvudpersonen död. Hon säger:

Det är tur att fåglarna finns, och likmaskarna, och förruttnelsen. Om vi döda inte låg $i$ jorden och förmultnade skulle vi vara till himlen travade, skyskrapor och torn av döda. Jag tänker ofta på hur många vi är, vi som redan har lämnat, så oändligt många fler än ni som är kvar. Och ändå kan vi inte göra er någonting. Ni kan göra vad ni vill med oss, säga vad ni vill, kasta svart jord över oss och berätta vilka historier ni har lust med. Ingen kan kontrollera fakta med oss, det är det som är så skönt med oss döda. Den döda är den perfekta vännen, hon som aldrig säger emot, och vi förändras aldrig, vi förblir samma

Minneapolis: Graywolf Press 2004, s. 48. Översättning till svenska: SS. 
som vi alltid har varit. Stelnade målningar. På två generationer är en människa bortglömd, det mänskliga minnet är inte längre än så. ${ }^{6}$

Ett problem i den sydafrikanska förlåtelseprocessen var den groteska skillnaden mellan de rika, som framför allt var vita, och de fattiga, som framför allt var svarta, en skillnad som i sig var ett resultat av den rasism och det våld som kallades för apartheid. Och det var de fattiga som var offren och de skulle förlåta trots att maktordningen, det vill säga de orättfärdiga ägandeförhållandena, bestod. ”Ni kan se min himmel som det möjligen enda konsekventa inslaget i mitt politiska liv: min misstro mot försoning. [...] Jag anser att försoning kräver min utplåning”, skriver den sydafrikanska författaren Njabulo S. Ndebele i Winnie Mandelas klagan. ${ }^{7}$ Den sydafrikanska poeten Koleka Putuma skriver i Collective Amnesia:

Synden är inte handlingarna som kommer att skicka svarta människor till helvetet. Synden är handlingarna vi begår i revolutionens namn. Helvetet är våra förfäders uppochnervända gravar för att hämnas sanningen. Vad förväntade ni er? Ni lever i ett hemsökt hus och kallar er fria eller förlåtna. Berätta för dem att halleluja låter som svarta människor som rapar: RÄTTVISA! RÄTTVISA! RÄTTVISA! RÄTTVISA! [...] RÄTTVISA! ${ }^{8}$

6. Sara Stridsberg, Kärlekens Antarktis: roman, Stockholm: Albert Bonniers förlag 20I8, s. 80-8I.

7. Njabulo S. Ndebele, Winnie Mandelas klagan, översättning till svenska: Boel Unnerstad, Stockholm: Tranan 2007, s. 198, 200."I give you my heaven as possibly the single element of consistency in my political life: my distrust of reconciliation. [...] For me, reconciliation demands my annihilation." Njabulo S. Ndebele, The Cry of Winnie Mandela: A Novel, Banbury, Oxfordshire, UK: Ayebia Clarke Publishing Limited 2004, s. I36-I37.

8. Koleka Putumas dikt "Afterlife": "sin / will not be the acts / that will send black folk to hell / sin will be the acts / we will commit in the name of the revolution // hell / will be the graves of our forefathers turned inside-out / to revenge the truth // what did you expect, / living in a haunted house / and calling yourself free and pardoned? // tell them Hallelujah sounds like / black people / burping: / JUSTICE! / JUSTICE! / JUSTICE! / JUSTICE! [...] JUSTICE!", Koleka Putuma, Collective Amnesia, Cape Town, South Africa: Uhlanga 20I7, s. III. Översättning till svenska: SS. Den grafiska utformningen motsvarar inte originalets. 
Litterära motröster mot rösterna som talar om försoning och framtid.

Sydafrika har den högsta andelen våldtäkter av kvinnor och barn i hela världen. Vittnesmålen om våldtäkt i Sanningskommissionen exponerade också kvinnorna för en annan sorts våld. Det vill säga den våldsamma skugga som alltid kastas över den våldtagna kvinnan: misstron, skulden. I samma ögonblick som hon berättar tycks hon alltid släpas i en osynlig smuts. Och eftersom våldtäkterna har fortsatt även efter försoningsprocesserna, men i form av privata, ickepolitiska händelser, så hamnar våldtäkten på ett vis utanför den stora förlåtelsen, skriver filosofen Louise du Toit. ${ }^{9}$ Frågan om förlåtelse är ju bara möjlig att ställa efter en tid av icke-våld, efter en omdefinition av maktrelationerna, inte så länge våldet pågår.

När guvernören George W. Bush godkände avrättningen av Karla Faye Tucker 1998 i Texas gjorde han det med hänvisning till att han lämnade över uppgiften till Gud att döma henne, det vill säga förlåta henne eller göra dess motsats. Men man skulle också kunna säga att dödsstraffet är en manifestation av det oförlåtliga.

Hur som helst, i rummet där Karla Faye Tucker ska dö händer det oerhörda, där kliver offrets bror Ron Carlson över en historisk gräns. För första gången någonsin i amerikansk historia väljer en anhörig att bevittna en avrättning på förövarens sida i stället för på offrets, $i$ det här fallet var offret hans syster.

Det är något med tiden eller gravitationen eller så är det grammatiken och språkets lagar, någonting med själva alfabetet. När jag försöker tänka på det oförlåtliga hamnar jag ohjälpligt i förlåtelsen. Kanske för att förlåtelsen ligger alldeles intill det oförlåtliga. Kanske för att det egentligen är samma sak.

Jean Améry, författare och överlevare från Förintelsen, orkade inte med att Nietzsche alltid skulle ha sista ordet när det kom till förlåtelsen.

9. du Toit, "Våldtäktsfrågan", s. 72. 
För trots allt hade allt Nietzsche någonsin skrivit kommit till före år I900, filosofen hade ingen aning om hur nittonhundratalets brott mot mänskligheten skulle se ut. Och där Nietzsche hänvisade till moralen hänvisar man i dag ofta till psykologin när det kommer till imperativet att förlåta. Man bör inte bli fånge hos det förflutna, bli kvar $i$ sin vingbrutenhet etcetera. Men, skriver Améry, tänk om sjukdomen (den personliga, psykologiska, avvikande, den vilda smärtan) och dess symptom i själva verket är en moralisk sanning som säger någonting om den värld vi lever i och att botas från denna sjukdom vore något helt omoraliskt. Han skriver: "Jag [...] är inte 'traumatiserad', utan mitt andliga och psykiska tillstånd stämmer snarare helt och hållet överens med verkligheten [...]."10

Améry skulle säga att förlåtelse är att ge upp sin individualitet och bara bli en social funktion i samhället."Min fula oförsonlighet”, ${ }^{11}$ som han kallar det. Han menar att han tillhör en liten minoritet som inte vill förlåta medan gaskammarkonstruktörernas generation kräver att han försonas. Han själv kräver det gjorda ogjort, att tiden dras tillbaka, varken mer eller mindre. ${ }^{12}$ Och där Desmond Tutu hävdar att det utan förlåtelse inte finns någon framtid ställer Améry frågan varför framtiden skulle vara mer värd än det som var gårdagen. Det som för icke-offren var tolv år i Nazityskland var för offren tusen år, skriver han. ${ }^{13}$ Och "den värld som förlåter har dömt mig och inte dem som mördade och lät morden ske". ${ }^{14}$ Han håller fast vid det oförlåtliga för att rädda sig själv och för att rädda Tyskland: "Ingenting kan invagga mig i den trygghetens slummer ur vilken jag vaknade upp 1935. " Han fortsätter:

Io Jean Améry citerad i Roy Ben-Shai, "Att leva utifrån: om Jean Amérys moralfilosofi", översättning till svenska: Malin Lundh, Glänta 4.06 Sanning och försoning, Göteborg: Glänta, s. 55, citat s. 59. Tillgänglig även elektroniskt: http://glanta.org/ tidskrift/alla-nummer/?viewArt=ıoro (hämtad 28/8 2019). Se även Jean Améry, "Ressentiment", översättning till svenska: Tommy Andersson, Glänta 4.06 Sanning och försoning, Göteborg: Glänta, s. 42-53.

II. Améry,"Ressentiment", s. 47.

I2. Ibid., s. 46 .

13. Ibid., s. 51.

I4. Ibid., s. 49-50.

I5. Améry citerad i Ben-Shai,"Att leva utifrån”, s. 54 . 
$\mathrm{Ni}$ vill inte lyssna? Lyssna ändå. Ni vill inte veta vart er likgiltighet när som helst åter kan leda er och mig. Det ska jag tala om för er. Det angår inte er vad som hände för ni visste inte, ni var för unga eller var inte ens födda då? Ni borde ändå ha sett, er ungdom ger er inget fribrev. Bryt med era fäder. ${ }^{16}$

Det grymma är att tiden är på förövarnas sida. Tiden är på de levandes sida, de döda har inte en chans mot de levande. Améry söker en väg ur den ensamhet förföljelsen försatte honom i. Han vill nå en punkt där förövaren är med honom, och för ett ögonblick förenas med sitt offer, och lika hett som offret önskar det gjorda ogjort. En punkt där tiden upphävs och förövaren surras fast vid sitt brott. Att kräva det omöjliga må vara ett sorts vansinne och offren som vägrar att försonas blir alltid en sorts galningar, rättshaverister, som hänger och dinglar i sina gamla rep över verkligheten. Och kanske är det en sådan vild handling som Derrida kallar verklig förlåtelse, att förövaren och den utsatta rör sig neråt i tiden och möts. Att vi alla simmar mot historiens riktning, mot gravitationens och tidens lagar, och försöker övervinna det oövervinneliga genom att göra det omöjliga. Det handlar inte om framtiden, utan om det förflutna, att böjas till tankens absoluta gräns, tillbaka till det oförlåtliga, och att stå kvar där, stå ut där, bli hängande mellan himmel och jord.

Kanske befinner sig litteraturen, när den är som störst, alltid vid tankens gräns. Kanske handlar litteraturen om att stå ut med det oförlåtliga. Jag har alltid sökt ett språk som står på vansinnets sida. Vansinnet är också bara att vägra acceptera verkligheten som den är, att göra uppror mot den.

Det finns en tysk konstnär som heter Anna Schuleit som jag älskar, hon har i sin konst ägnat sig åt att fylla gamla mentalsjukhus i USA med blommor och med musik. När jag skrev min roman Beckomberga ${ }^{17}$ om en flicka, som i delar liknar mig och som besöker sin

I6. Ibid., s. $5^{8}$.

I7. Sara Stridsberg, Beckomberga. Ode till min familj, Stockholm: Albert Bonniers förlag 2014 . 
pappa på ett mentalsjukhus, var hennes konst helig för mig. I verket Bloom (2003) placerar hon 28 ooo blommor på Massachusetts Mental Health Center, en blomma för varje patient som aldrig fick besök. Det är en oskriven lag: när du besöker någon i den somatiska vården tar du med dig en blomma. Inte till psykiatrin, och särskilt inte till patienterna på de gamla mentalsjukhusen. I ett annat verk, Habeas Corpus (2000), placerade Anna Schuleit Io2 högtalare i det nedlagda Northampton State Hospital i Massachusetts, det skulle just rivas efter att ha stått övergivet i åratal, och lät J.S. Bachs Magnificat strömma ur byggnaden. Hon har sagt att hon ville att byggnaden skulle sjunga. Jag har sett fotografierna från det tillfället, då människor i staden hör ljudet dåna ur det gamla sjukhuset och går i dess riktning. Sjukhuset, liksom alla de gamla mentalsjukhusen, låg en liten bit utanför de stora städerna, även om städerna med tiden kröp närmare, liksom utkastade ur gemenskapen, som om det var ett brott de hade begått, de som vistades där. Människor vars enda misstag bestod i att de var för sköra för denna världen, för nittonhundratalets allt snabbare rörelser, för själva existensen. Men i omvärldens ögon var de inte bara fallna utan också dömda, monstruösa, oönskade. Hur ska de kunna förlåta världen för det?

Kanske är det en förlåtelse som är omöjlig eftersom skyldig och oskyldig har bytt plats här, på samma sätt som vid till exempel prostitution, där världen placerar den sexuella skulden och skammen hos kvinnan i stället för hos den köpande mannen, trots att hon måste vara den mest oskuldsfulla människan i världen. Utan egen sexualitet i stunden, utan närvaro, erotik och utlevelse, upplåter hon sig till andras drifter. Ändå blir hon den som härbärgerar skammen, hon blir den skyldiga. Och den skyldiga är den som ber om förlåtelse.

Den utsatta får skulden för sin utsatthet. Den som hävdar den svagas rätt blir uppspikad på ett kors. Flyktingen får skulden för att hon inte har någonstans att ta vägen med sitt sår. Världen förblir sina omskrivningar och bortförklaringar. Kollektiva lögner och bedrägerier, illusioner. Jag skulle säga att frågan om förlåtelse inte är möjlig förrän de stora berättelserna stämmer överens med den verklighet som de sägs spegla. Det är som med de vackra grå hajarna i oceanerna, som fanns här redan före oss, redan före dinosaurierna. I berättelsen om hajarna är det alltid de som utgör ett hot mot människan trots att vi 
vet att hajen bara dödar några få av oss varje år medan människan årligen dödar hundra miljoner hajar i hajfensfiske.

Att förstöra planeten jorden, och livet för även andra arter än vår egen, blir vår sista oförlåtlighet, och den yttersta. Man skulle kunna säga att det verkligt oförlåtliga i det fallet är att offren för denna katastrof inte kommer att ha den suveränitet som krävs för att över huvud taget kunna fundera över frågan om att förlåta detta oförlåtliga.

Eftersom de är barn, och eftersom de kommer att vara döda när frågan om förlåtelse för vårt oförlåtliga leverne skulle kunna aktualiseras. Det kommer också vi, som skulle kunna vara mottagare av denna eventuella förlåtelse, att vara. En död värld där frågan om förlåtelse slutgiltigt är överspelad. Bara det svaga ljudet av ett tomt hav som slår i fjärran.

Om förlåtelse kräver att tiden upphävs, att det gjorda förblir ogjort, så är kanske litteraturen platsen där det oförlåtliga och förlåtelsen kan få existera sida vid sida. I litteraturen finns ingen bestämd tid, där har allting redan hänt samtidigt som ingenting ännu har inträffat. Där står jag ännu i ljuset med min pappas hand i min. Jag har följt med honom till det gamla sjukhuset, för att han inte ska vara ensam där, för att inte någon dåre ska vara ensam. Och kanske är verklig förlåtelse, den drömlika vansinneshandling som ligger utanför allt vad vi kan föreställa oss, att springa tillbaka i tiden, och söka upp sina föräldrar där de befinner sig i sin omöjliga början och försöka skydda dem från mörkret som är på väg att dra in över dem. Även om det betyder att du själv då kanske aldrig skulle ha blivit till. För att stoppa de förbannelser som vilade över en familj som vår och som längre fram i vår historia skulle komma att leda till oförlåtliga handlingar. 